\title{
Community Activities and the Impacts on the Environment at Krau Wildlife Reserve, Malaysia
}

\author{
Che Bon Ahmad ${ }^{1,2}$, Jamalunlaili Abdullah ${ }^{1}$, Jasmee Jaafar $^{2}$ \\ ${ }^{1}$ Centre for Environmental Design \& Management \\ ${ }^{2}$ Centre of Geospatial Technology \\ Faculty of Architecture, Planning and Surveying, \\ Universiti Teknologi MARA, Malaysia \\ chebon848@salam.uitm.edu.my, cb2_nismo@yahoo.co.uk
}

\begin{abstract}
Protected Areas (PAs) are signißcantfor ecosystem and communities. Studies suggested that land use activities carried out by the community surrounding the PAs could increase the pressure to the latter. Thus, this study is to identify the land use activities carried out by them, and to ascertain its spatial impact towards KWR. This study chooses a RS techniques and ground verißcation using GPS. 7he ßndings conßrm that there are land use activities performed by the communities, mostly on flat and less at hilly and undulating areas. Large scale plantations and encroachment are the major impact on the KWR.
\end{abstract}

Keywords: Protected Areas; community; land cover and land use activities; remote sensing techniques; GPS; ground verißcation; Krau Wildlife Reserve

eISSN 2514-751X @ 2018. The Authors. Published for AMER ABRA cE-Bs by e-International Publishing House, Ltd., UK. This is an open-access article under the CC BY-NC-ND license (http://creativecommons.org/licenses/by$n c-n d / 4.0 /$ ). Peer-review under responsibility of AMER (Association of Malaysian Environment-Behaviour Researchers), ABRA (Association of Behavioural Researchers on Asians) and cE-Bs (Centre for EnvironmentBehaviour Studies), Faculty of Architecture, Planning \& Surveying, Universiti Teknologi MARA, Malaysia.

https://doi.org/10.21834/aje-bs.v3i8.277 


\subsection{Introduction}

Worldwide, Protected Areas (PAs) has become an alternative solution to provide a balance ecosystem for the conservation of biodiversity and supporting life of the people living around the area and approximately, $11.2 \%$ of the world's forest has been dedicated for this purpose (Duong \& Murayama, 2010; Food and Agriculture Organization of the United Nations, 2005). This is in linewith the recognized definition provided by the International Union for Conservation of Nature (IUCN) (2008) - "a clearly defined geographical space, recognized, dedicated and managed, through legal or other effective means, to achieve the long term conservation of nature with associated ecosystem services and cultural values".

In Malaysia, some of the examples of the PAs categorized under the IUCN are Fraser Hill Wildlife Reserve, TasikCini Wetlands, Taman Negara Pahang andBatu Gajah Bird Reserve. They have been gazetted under the various acts and enactments such as National Park Act 1980, The Protection of Wildlife Act 1972, Forestry Act and National Land Code 1965 ((Deparment of Wildlife and National Parks Malaysia, 2001).

To date, PAs not only meant for conservation but its significant purposes have become a source of living for the communities, a melting pot for nature tourism, and a solution to climate change including carbon sink and temperature stabilization(DeFries, Karanth, \& Pareeth, 2010; MacKinnon, Dudley, \& Sandwith, 2011; Nyaupane \& Poudel, 2011; Stræde \& Treue, 2006). At least $15 \%$ of terrestrial carbon in the world is stored by the Protected Areas(IUCN, 2008). However, while the PAs are intact, the areas surrounding it may be not. Activities at the periphery, as well as pressures on the environment caused by economic development and other human activities make it difficult to protect the PAs. Thus, the need for PAs must be clearly understand and accepted by the decision maker and the general public in order to avoid the demand from the economic development supersede the conservation obligation.

\section{Purpose of Study and Study Area}

The purpose of this study is to document the land use activities carried out by the communities surrounding KWR - typical terrestrial Pas in Malaysia and a pilot project for wildlife conservation. The study area is located partly in the districts of Temerloh, Bentong and Raub in the state of Pahang, Malaysia. It covers approximately 62,000 hectares and is one of the important PAs in Malaysia. The study alsoidentifies the activities which have encroached and gave impact into the area. It is further determines the physical factors that facilitate or hinder the encroachment activities from the surroundings such as accessibility, water bodies, terrain, dense forest and others.

Unfortunately, KWR has been subjected to pressure from ever growing activities around it such as encroachment and conversion of land uses, degazettment, over hunting and over harvesting of non-timber product and agricultural activities. Furthermore, the existence of stakeholder andlocal community, especially indigenous people in and around it contributed to the decline of the ecosystem as well. 


\subsection{Methodology and Limitation of the Study}

As a primary data collection, GPS and topographic map were used for the purpose to identify and verify the current land use activities around the study area. RS technique being the secondary data collection was used to support and strengthen the primary data. This technique is the preferred choice due to relatively fast and effective way of detecting changes of land use activities at the regional scale. This study focused on the spatial land use activities, primarily the built-up area and the economic activities carried out by the local communities. Figure 1 shows the workflow of the research used for this study.

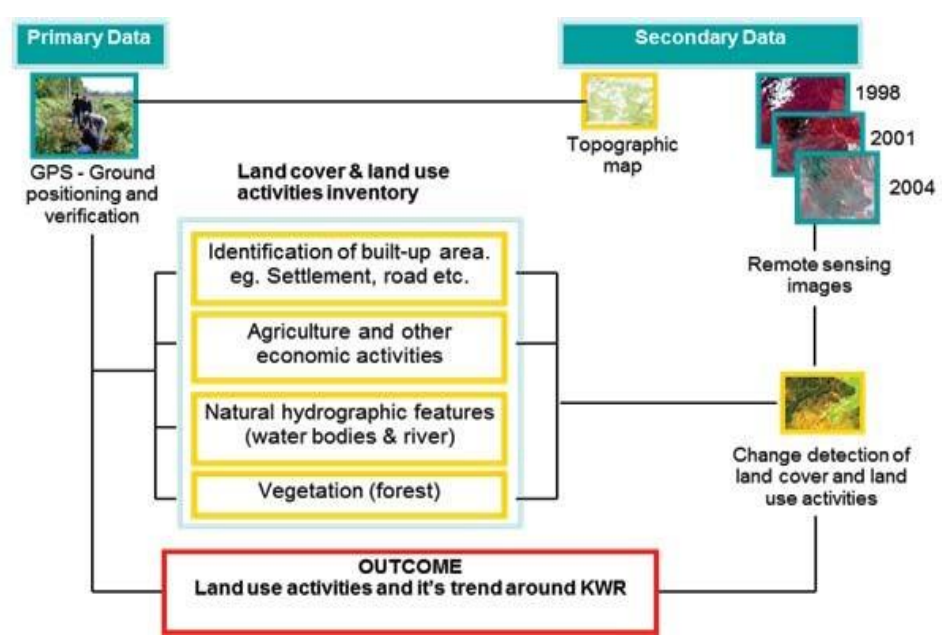

Figure 1: Workflow of Research Activities

\subsection{Primary Data Collection -Ground Positioning and Verification}

Data collection was carried out along the boundary of KWR,derived from the available topographic map. The process involvedthree stages (Figure 2) and the records were gathered using the Inventory Form below (Table 1).

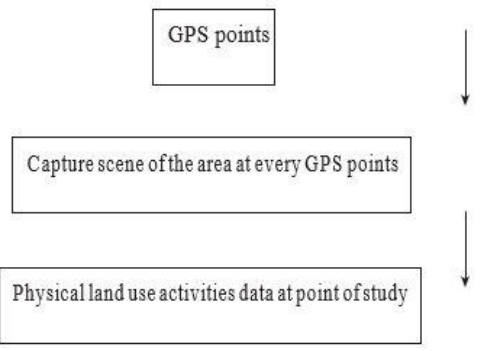

Figure 2: Flow Chart of Ground Positioning and Verification Process 
Table 2: Land Cover and Land Use Inventory Form

POINT ID:

1

GPS READING/COORDINATES: E 468825

N 426673

\begin{tabular}{|c|c|c|c|c|c|c|c|c|c|c|c|c|c|}
\hline A Hydrography & B & Accessibility & & c & Settlement & & D Vegetation & & & Agriculture & F & Slope & Remarks \\
\hline \begin{tabular}{|l|l|}
1 & Lake \\
\end{tabular} & & Railway & & 1 & Research office quarters & & 1 Primary forest & & $1 \mathrm{~F}$ & Plantation & 1 & Flat & Boundary \\
\hline 2 Pool & & Highway & & 2 & Orang Asli settlement & & 2 Secondary forest & & 2 & Farm & 2 & Gentle & \\
\hline 3 Reservoir & 3 & Carriage track & 1 & 3 & Malay settlement & 1 & 3 Grassland & 1 & 3 & Orchard & 3 & Moderate & crossing \\
\hline \begin{tabular}{l|l}
4 & River \\
\end{tabular} & 4 & Unsealed track & & 4. & Chinese settlement & & 4 Open space & 1 & & Others & 4 & Steep & carriage \\
\hline 5 Stream & 5 & Motorable track & & 5 & Others & & 5 Others & & & (eg. Nomad) & & & track \\
\hline 6 S wamp area & 6 & Footpath & & & & & & & & & & & \\
\hline 7 Others & & Others & & & & & & & & & & & \\
\hline
\end{tabular}

The variables used in the form (Table 2) above were derived from the topographic map acquired from the Malaysia Surveying Department such as accessibility, settlements, agriculture and hydrology. GPS receiver (Garmin GPS e_Trex Summit) was used to locate the position of land use and other ground activities during the works. Digital images (Sony digital camera) were captured along the boundary at selected points with the radius of two kilometers and its coordinates determined.

The captured photos at the specific areas were divided into four (4) sections, each facing different geographical directions (Figure 3). Some sections with similar information are represented by less than 4 photos. Figures 4 and 5 below showed the example of photos taken during the fieldwork at the respective points.

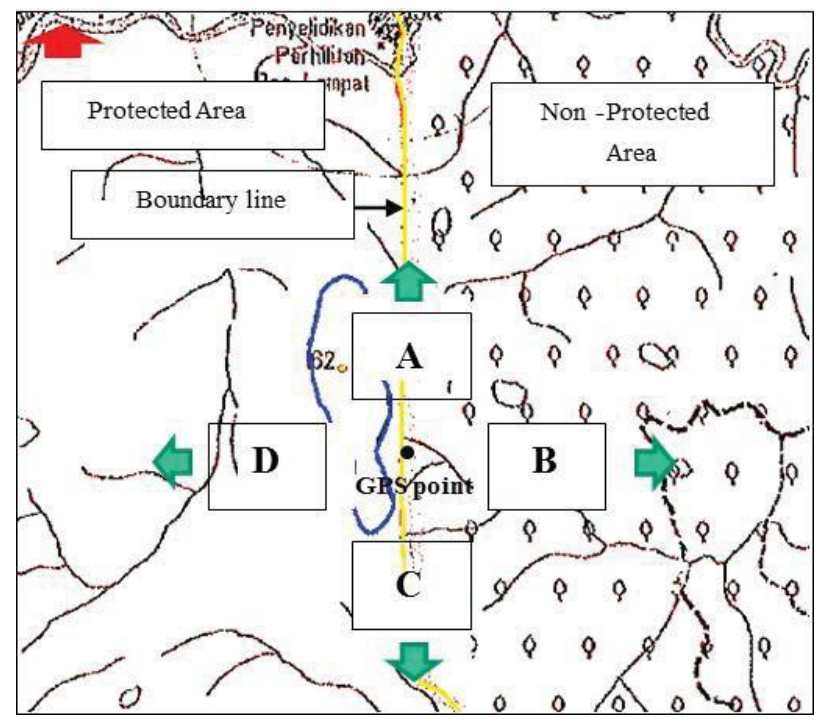

Figure 3: Image Point Index 

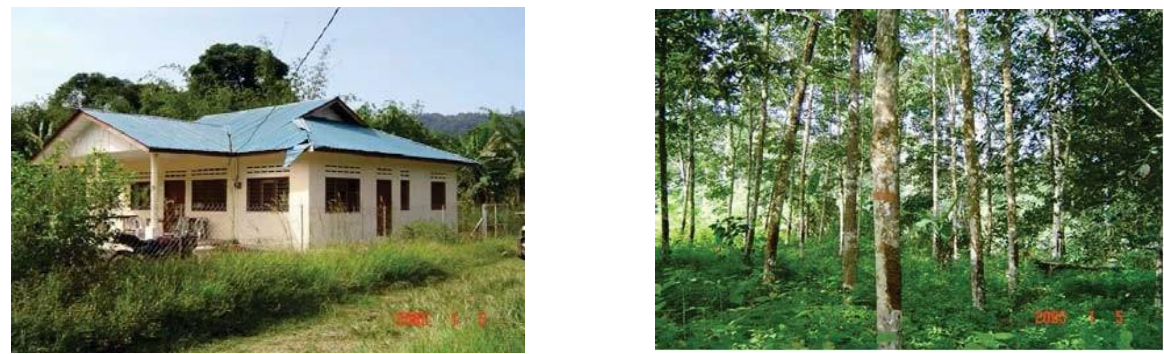

Figure 4: (a) Community Hall (A); (b) Rubber Trees (B)

Figure 4. (a) is the example of photo taken at Point ID: 6 (coordinates: E 471949m, N 417334m) and (b) is the example of photo taken at Point ID: 17 (coordinates: E 479230m, N 406035m).
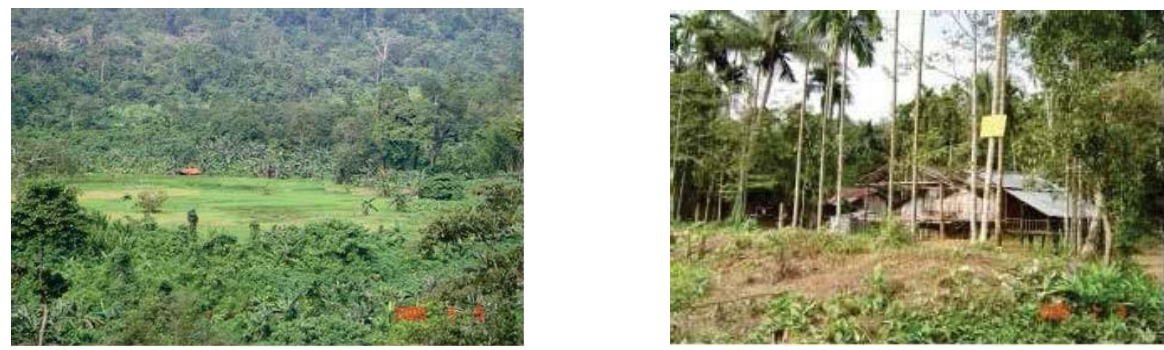

Figure 5: (a) Paddy Field (D); (b) Setlement of Indigenous Community (D)

Figure 5. (a) is the example of photo taken at Point ID: 23 (coordinates: $E 47712 \mathrm{~m}, \mathrm{~N}$ 402049m) and (b)is the example of photo taken at PointID: 27 (coordinates: E 477031m, N $401374 \mathrm{~m})$

\subsection{Secondary Data Collection - Remote Sensing Technique}

Figure 7(a) shows the flow of the remote sensing data processing using LANDSAT Thematic Mapper (TM) optical images with 30m pixel size were obtained from Malaysia Remote Sensing Agency. The images were captured in 1998, 2001 and 2004 with the areas of $1000 \mathrm{X}$ 1000 pixels covering approximately $900 \mathrm{~km}$ square.

Figure 7(b) shows an example of an image taken in year 2004 and the study area covered is from $3^{\circ} 50^{\prime} \mathrm{N}, 101^{\circ} 55^{\prime} \mathrm{E}$ (Upper Left) to $3^{\circ} 35^{\prime} \mathrm{N}, 102^{\circ} 25^{\prime} \mathrm{E}$ (Lower Right). Land cover and land use patterns are to be classified by its pattern. Some items are similar to each other, and a simplification is to be reduced the pattern to three types namely; vegetation (forest), agricultural area and built-up area. The three classes of classification are enough for the purpose of this study which is mainly to identify the area and direction of the land use changes especially agriculture and built-up area. Supervised classification was used, and 
Ahmad, C.B., et.al. / Asian Journal of Environment-Behaviour Studies (ajE-Bs), 3(8) May / Jun 2018 (p.33-44)

MaximumLikelihood Algorithmwasemployed to detect the types of classification. An accuracy assessment has also been done to determine the accuracy of the classification process.
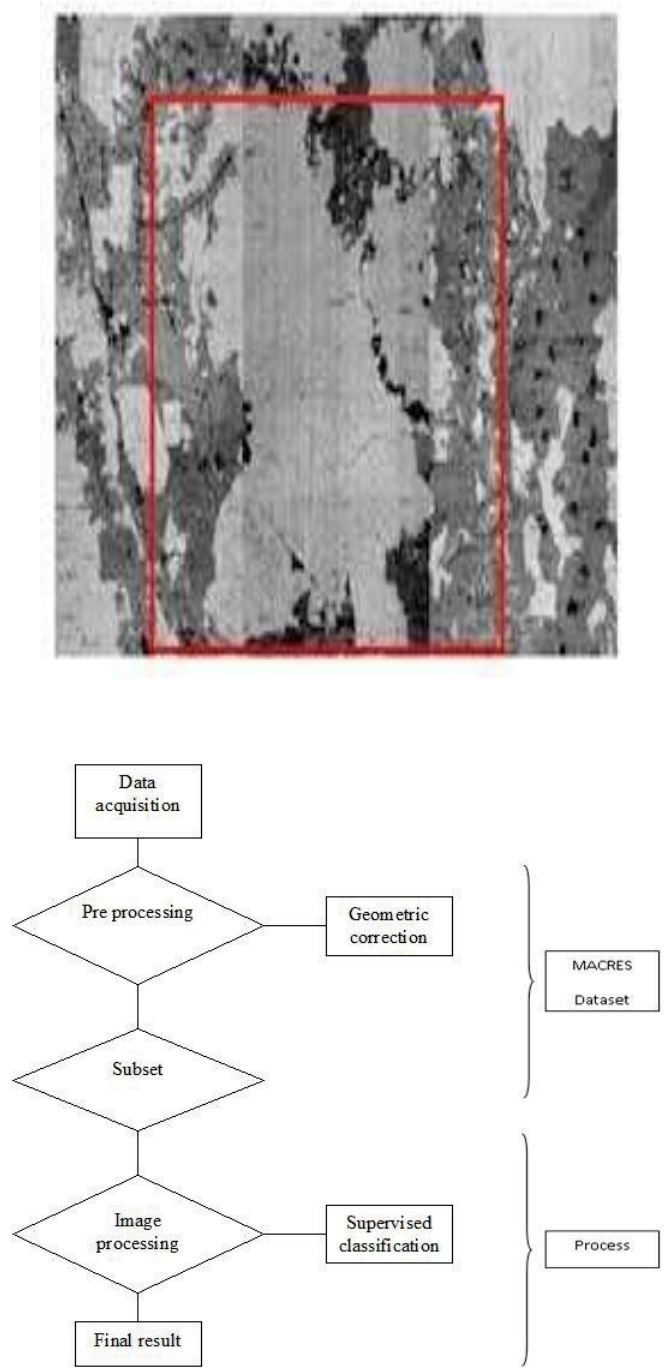

Figure 7: (a) Flow of Remote Sensing Data Processing (b) Example of Image 


\subsection{Results}

\subsection{Ground positioning and verification of land use activities}

Forty three (43) GPS points had been identified along the boundary with two (2) kilometers interval. However, distance interval varies at areas with accessibility difficulties, dense forest or steep slopes. Each point has been elaborated by the information of the related land-use activities. Seventy three (73) photos had been taken to represent the points. At points with similar land use activities, only one or two photos were taken to represent the area.

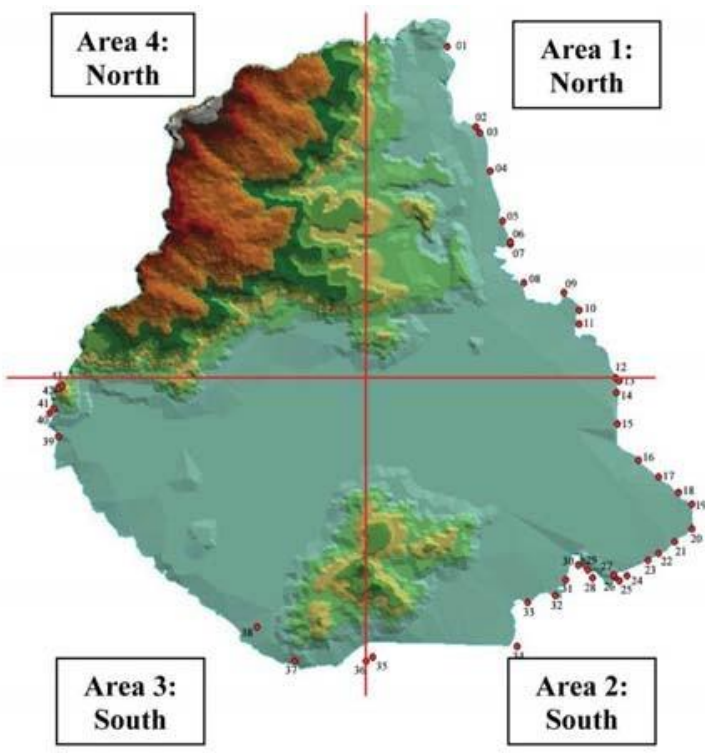

Figure 8. The Quadrants Designated and GPS Coordinates along the Boundary of the KWR

Since the land use activities are quite similar throughout the area and for the purpose of the analysis, the area has been divided into four (4) quadrants only. The designated areas are: Area 1-North East which covered the GPS points from 1 to 12, Area -: South East which covered the GPS points from 13 to 35, Area 3- South West which covered the GPS points from 36 to 43 and Area 4- North West which covered none of GPS points due to the accessibility difficulty into the dense forest and very hilly area.

In this study, it was found that major farming activities are observed at Area 1- North East section of the study area. The activities are carried out by indigenous community in particular, and other local communities are encroached into the KWR and their settlements are in the vicinity. Human activities are found mostly at low land with moderate slope and areas which has water bodies and road networks. This condition support activitiesincluding paddyand rubberfarm. Theseactivitieshaveencroached into the KWR at certain areas. 
Area2-South East section shows high tendency of encroachment into the KWRby oil palm and rubber farm. Settlements unit of the indigenous community along and inside it is also part of the human activities perceived. Area 3: South West section experienced similar activities to Area 1 and 2 whilst at some areas, tendency of encroachment of smaller orchard are also in the vicinity. Surprisingly, Area 4: North West section experienced little or no human activities. This might due to the area concern comprises of hilly, undulating and dense forest. Little to no human settlement and minor farming such as non-seasonal fruit trees are recorded.

\subsection{Remote Sensing Data}

Figure 10 shows the land uses activities which are built-up area and agriculture increases from 1998 to 2004 and some activities have encroached into the KWR.

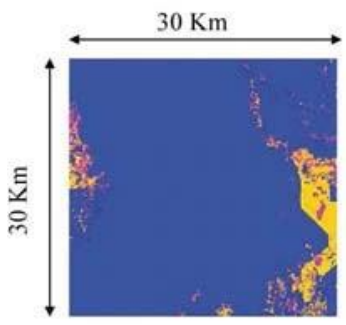

Year 1998

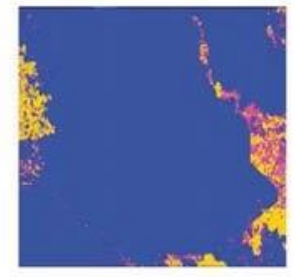

Year 2001

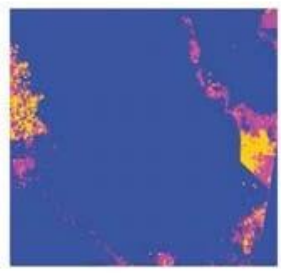

Year 2004

Legend

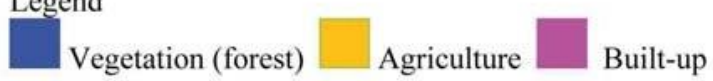

Figure 10: Classification Area of Land Cover and Land Use Activities at Krau Wildlife Reserve Andits Surrounding Areas

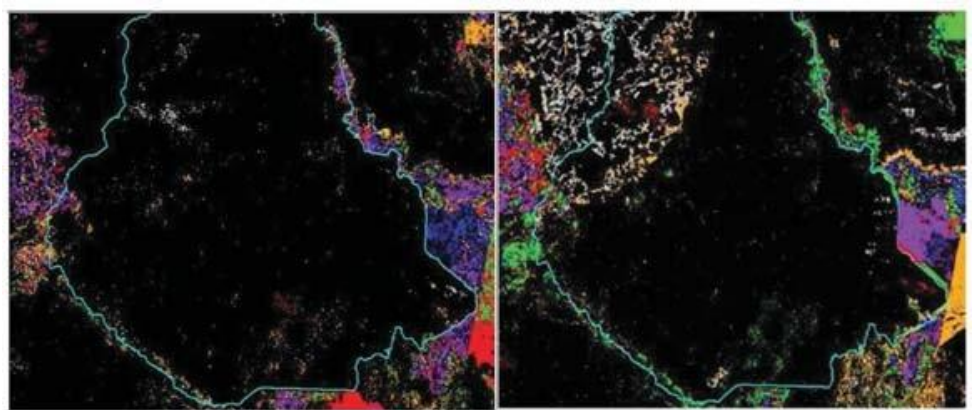

Figure 11: Change Detection of Land Cover and Land Use Activities at KWR and its Surrounding Areas between (a) 1998 - 2001; (b) 2001 - 2004 
Figure 11 shows the changes that were taken place in KWR and its surrounding. Likewise, Table 3 shows the percentage of the changes occurred in the study area.Built-up area has taken up the agricultural area in 2001 and 2004, respectively. In general, most of the changes occurred at the east and west side.

Table 3: Percentage of Changes of Land Cover and Land Use Activities

\begin{tabular}{|c|c|c|c|c|c|}
\hline \multirow{3}{*}{$\begin{array}{l}\text { Class } \\
\text { No changes }\end{array}$} & \multirow[b]{2}{*}{ Color code } & \multicolumn{2}{|l|}{$\begin{array}{l}1998 \text { to } \\
2001\end{array}$} & \multicolumn{2}{|l|}{2001 to 2004} \\
\hline & & $\begin{array}{l}\text { Areas } \\
\text { (becterss) }\end{array}$ & centage & $\begin{array}{l}\text { Areas } \\
\text { (bectaces) }\end{array}$ & Percentage \\
\hline & & 82122,84 & $85 \%$ & 88638,03 & $91 \%$ \\
\hline Vegetation & & 7204,86 & $-7 \%$ & 3074,04 & $-3 \%$ \\
\hline Agriculture & & 3892,05 & $+4 \%$ & 1790,46 & $-2 \%$ \\
\hline Built-up & & 3536,73 & $+4 \%$ & 4319,55 & $+4 \%$ \\
\hline Total & & 96756,48 & $100 \%$ & 97822,08 & $100 \%$ \\
\hline
\end{tabular}

Agricultural area has increased about 4\% from 1998 to 2001 but decreased about 2\% from 2001 to 2004. It is because the built-up area has taken the $2 \%$ of the agricultural area while the built-up area has increased about 4\% from 1998 to 2001 and continues to increase another 4\% from 2001 to 2004. Vegetation had decreased about 7\% from 1998 to 2001 and continues to decrease another $3 \%$ from 2001 to 2004 at the respective areas. It is also shown that generally the pattern of changes were from vegetation to agriculture, and to the built-up area.

\subsection{Discussion}

\subsection{Type of Activities and Encroachment}

The findings have suggested that the community around Krau Wildlife Reserve especially indigenous communities have performed various activities to support their living, self-use and substitute to the extraction of natural forest product from Krau Wildlife Reserve which they are permitted by law. The activities include small plot of rubber farming, cultivating of seasonal and non-seasonal crops, paddy fields, banana, pineapple etc. Some of activities including their settlements are encroached into the Krau Wildlife Reserve resulting in potentially negative impacts to the conservationarea. Although their activities poses negative impact to Krau Wildlife Reserve, it is worth taking into consideration the plantation activities carried out by the larger company such as FELDA. It was found that the plantation has taken place right up to the border of the area. Thus, it may contributed to the negative impacts due to abrupt change in land use activities between Krau Wildlife Reserve and agriculture such as edge effects resulting of dying of forest trees and wildlife leaving the conservation area. 


\subsection{Factors Determining/Supporting the Activities}

Based on the GPS-ground positioning and verification, and remote sensing images, farming activities which have been carried-out by the communities have performed a high encroachment at north-east area followed by south-east and west-side. This is due to the areas are relatively lower and flat areas, and areas which have access such as the road network and water bodies. Otherwise, undulating and steep slopes covering north- west side hinder human activities such as cultivating of seasonal crops and other farming activities as well as settlements. Flat areas may provide easy accessibility from the surrounding while higher elevation areas restricted the accessibility. Thus, human activities became limited.

\subsection{Factors Determining the Intensity of the Land Use Activities}

Remote sensing images suggested that the area has gone through a series of changes. Vegetation area has changed to agriculture and built-up area between the year 1998 to 2001 and 2001 to 2004, respectively. Overall, it was found that the intensity of the changes has occurred at the east and west side of the area. From the topographic map, it is suggested that most of the changes occurred at flat areas and decreased in hilly and undulating areas. This might be due to the increased of the population which required more opening of land for agricultural and settlement area. This shows that, dense forest, hilly and high elevation areas are not prone to human activities and settlement. The overall findings suggested that most of the area experienced encroachment of farming activities by indigenous people and local community at the flat areas due to easy accessibility and farming activities, and less at hilly areas.

This study can be summarized into the following points:

1) Flat areas indicate the high possibilities of encroachment activities. This may due to the area provide an easy access to the indigenous people and other local communities to enter the Krau Wildlife Reserve and increased of the population of the areas. This factor suggested that land use activities occurred mostly at low land and flat areas.

2) However, areas which are subject to hilly, high peak and dense forest should shows that minimum to no encroachment activities are carried out at these areas. This may due to the difficulties to access areas.

3) Areas which involved water bodies (river), road networks and other similar activities performed significant changes of the land use activities because it support various human activities such as farming, land clearing and settlements.

\subsection{Conclusion}

Identifying the land use activities around the PAs is very important in order to minimize the negative impact from the outside and to safeguard the significant of the PAs, in this case KWR. Encroachment by communities has proven gave a great impact to the area. The advancement of the built- up area and agriculture increased from 1998 to 2004 and in some areas, it had encroached into the KWR. Land cover, land use and vegetation area have changed to agriculture, and to built-up area from 1998 to 2004 and most of the changes occurred on the flat areas and decreased at the hilly and undulating areas. Activities such as 
land clearing, open burning, farming and settlement by indigenous communities in particular occurred mostly at low land, flat area and areas with water bodies, road networks and similar land uses while hindered at hilly terrain, high peaks and dense forest. Furthermore, large scale plantations were also observed at most of the surrounding areas and encroachment and fragmentation turn out to be two major impacts on the KWR. Thus, a better management is needed. It may include identifying the buffer zones around it, inclusion of local communities and stakeholder alliances. It is worthwhile to reach the balance between their (indigenous community being the majority) needs towards Krau Wildlife Reserve, and the conservation purposes. Besides land cover and land use (physical aspect) activities, other aspects could be of importance looking into are the stakeholders' participation and contribution, management objectives, and laws and policies which relates to the Protected Areas. This study also suggested that Buffer Zones may be one of solutions for a better management, prevent the Protected Areas from the negative impact of the surrounding activities. It is also suggested that although the Krau Wildlife Reserve is gazettes as a Protected Area, the encroachments is glaring and increasing. This may be due to the lacking of the enforcement of the law and policies or the economic and political requirement have superseded the value of the conservation of the natural areas.

\section{Acknowledgement}

The utmost appreciation goes to the Malaysian Remote Sensing Agency, Department of Survey and Mapping Malaysia and Department of Wildlife and National Park, for providing the data sets and other related information. This paper could not have been completed without the financial support received from the Research Management Institute, UniversitiTeknologi MARA and Ministry of Higher Education, Malaysia. Acknowledgement also goes to the peer reviewersfor reviewing and providing constructive comments for the manuscript.

\section{References}

Bennett, G. (2004). Integrating Biodiversity Conservation and Sustainable Use: A Lesson Learned From Ecological Networks. Switzerland and Cambridge, UK.: Gland.

Daim, M. S. (2003). National Seminar on Protected Areas in Malaysia, Ministry of Science, Technology and Environment, Malaysia.

DeFries, R., Karanth, K. K., \& Pareeth, S. (2010). Interactions between protected areas and their surroundings in human-dominated tropical landscapes. [doi: 10.1016/j.biocon.2010.02.010]. Biological Conservation, 143(12), 2870-2880.

Deparment of Wildlife and National Parks Malaysia. (2001). Protected Area Management Guidelines 1. Deparment of Wildlife and National Parks Malaysia: Deparment of Wildlife and National Parks Malaysia.

Fan, F., Weng, Q., \& Wang, Y. (2007). Land use and land cover change in Guangzhou, China from 1998 to 2003 based on Landsat TM/EMT+ imagery, Journal of Sensor 2007, 7, 1323-1342. Retrieved on June 10,

2010 from http://qihaoweng.net/refereed\%20journal/sensors_07.pdf. 
UCN, (2008). About Protected Areas, The World Conservation Union. Cambridge, UK.

Lillesand, T. M., Kiefer, R. W., \& Chipman, J. W. (2004). Remote Sensing and Image Intepretation (5th Ed.), John Wiley \& Sons Inc., NJ.

Liu, J., Ouyang, Z., \& Miao, H. (2010). Environmental attitudes of stakeholdersand theirperceptions regarding protected area-community conflicts: A case study in China. [doi: 10.1016/j.jenvman.2010.06.007]. Journal of Environmental Management, 91(11), 2254-2262.

MacKinnon, K., Dudley, N., \& Sandwith, T. (2011). Natural solutions: Protected areas helping people to cope with climate change. ORYX, 45(4), 461-462.

Marther, P. M. (1999). Computer Processing of Remotely-Sensed Images: An Introduction (2nd Edition), John Wiley \& Sons Ltd., UK.

National Resource Canada (2005).

Department of Town and Country Planing, (2011). National Physical Plan II , Kuala Lumpur, Malaysia.

Rastogi, A., Badola, R., Hussain, S. A., \& Hickey, G. M. (2010). Assessing the utility of stakeholder analysis to Protected Areas management: The case of Corbett National Park, India. [doi: 10.1016/j. biocon.2010.04.039]. Biological Conservation, 143(12), 2956-2964.

Stræde, S., \& Treue, T. (2006). Beyond buffer zone protection: A comparative study of park and buffer zone products' importance to villagers living inside Royal Chitwan National Park and to villagers living inits bufferzone. [doi:10.1016/j.jenvman.2005.03.017]. Journal of Environmental Management, 78(3), 251-267.

DeFries, R., Karanth, K. K., \& Pareeth, S. (2010). Interactions between protected areas and their surroundings in human-dominated tropical landscapes. [doi: 10.1016/j.biocon.2010.02.010]. Biological Conservation, 143(12), 2870-2880.

Deparment of Wildlife and National Parks Malaysia. (2001). Protected Area Management Guidelines 1. Deparment of Wildlife and National Parks Malaysia: Deparment of Wildlife and National Parks Malaysia.

MacKinnon, K., Dudley, N., \& Sandwith, T. (2011). Natural solutions: Protected areas helping people to cope with climate change. ORYX, 45(4), 461-462.

Nyaupane, G. P., \& Poudel, S. (2011). Linkages among biodiversity, livelihood, and tourism. [doi: 10.1016/j.annals.2011.03.006]. Annals of Tourism Research, 38(4), 1344-1366.

Stræde, S., \& Treue, T. (2006). Beyond buffer zone protection: A comparative study of park and buffer zone products' importance to villagers living inside Royal Chitwan National Park and to villagers livinginitsbufferzone. [doi:10.1016/j.jenvman.2005.03.017].Journal of Environmental Management, 78(3), 251-267. 